\title{
Quarter of a century of forest fertilization and liming research at the Department of Silviculture in Prague, Czech Republic
}

\author{
Josef Gallo*, Zdeněk Vacek, Stanislav Vacek \\ Czech University of Life Sciences Prague, Faculty of Forestry and Wood Sciences, Kamýcká 129, CZ - 16521 Prague 6-Suchdol, \\ Czech Republic
}

\begin{abstract}
Fertilization and liming began to be used in forestry at the beginning of the 20th century in order to increase growth, for improvement of health status or higher resistance to biotic and abiotic factors. The review summarizes results of 48 studies of forest fertilization, nutrition and liming published in scientific journals by authors of Department of Silviculture in Prague over the past more than 20 years. They deal mainly with monitoring of the effect of fertilization and liming applied during planting or shortly after planting of 18 tree species. Moreover, the results of fertilization in older stands are presented. Separate chapters deal with enhancing substrates (soil conditioners and phytohormones). All forest vegetation ranges are covered, from lowland forests to the subalpine belt of grass vegetation in 11 Natural Forest Areas. Forest fertilizing and liming proved beneficial according to most of the studies. The use of fertilizers can be detected in soils after decades. On the other hand, only in a minority of cases was fertilization reflected in the chemistry of the assimilation apparatus and other parts of the trees for a longer period. The main positive effect of fertilization and liming was increase of tree growth and foliation and decrease of mortality and yellowing symptoms. Inconsistent results were documented in some cases, especially for brassinosteroids and alginite compared to good results in slow release fertilizer done by spot-application. The type of product, concentration, time and method of application play an important role in the appropriate use of fertilization and liming.
\end{abstract}

Key words: afforestation; chemical amelioration; nutrition; tree resistance; growth increase

Editor: Bohdan Konôpka

\section{Introduction}

Forests respond slowly to management activities and the possibilities to increase the growth in a short-term perspective and meet swift increases in society demand for timber are small (Hedwall et al. 2014). At the same time, increased demands for timber and forest products can be expected as a result of current policies and climate change mitigations (Marland \& Obersteiner 2008; Daioglou et al. 2019; Vacek et al. 2021). At present, climate change due to long-term periods of drought, frequent climatic extremes and secondary bark beetle outbreaks causes unprecedented forest decline, increasing the salvage logging and negatively affecting production sustainability (Dobor et al. 2020; Šimůnek et al. 2020; Toth et al. 2020). Moreover, second problem are the enormously high game population and damage (browsing, bark striping, subsequent rot) on forests in the Czech Republic (Čermák et al. 2004; Cukor et al. 2019; Prokůpková et al. 2020; Vacek et al. 2020a). On the other hand, in terms of policy instruments, increased afforestation, biomass production and the associated carbon sequestration play an important role in climate change adaptation strategies (Cukor et al. 2017b; Law et al. 2018; Podrázský et al. 2020; Smith et al. 2020). All this can be positively affected by fertilization and liming of forest stands.

Fertilizers can be one of the ways to speed up plant growth, increase production efficiency and improve health status of forest stands (Saarsalmi \& Mälkönen 2001; Remeš et al. 2005; Fox et al. 2007). Over the last years, interest in fertilizing of forests is increasing, however forestry is still a minor user of fertilizers compared to agriculture (Smethurst 2010; Lindkvist et al. 2011). However, there may be both economic and environmental constraints on the large-scale application of fertilizers in forests (Hedwall et al. 2014). Fertilizers may not only increase the tree growth, economic profitable and climate change mitigation in relation to carbon store (Albaugh et al. 2019; Petaja et al. 2018). Enriched soils can also have a significant effect on wood quality (Mäkinen et al 2002; Cukor et al. 2020), ground vegetation (Hejcman et al. 2007; Strengbom \& Nordin 2008), seed production 
(Williams et al. 2003), mycorrhiza community (Baum \& Makeschin 2000; Klavina et al. 2016) and what is particularly important - on the health status of forest stands (Podrázský et al. 2005; Vacek et al. 2019b).

During the second half of the 20th century, Central Europe was strongly affected by air pollution, especially by high concentrations of $\mathrm{SO}_{2}$ and acid deposition (Małek et al. 2012; Král et al. 2015; Králíček et al. 2017; Putalová et al. 2019; Vacek et al. 2020c). In addition to the air pollution damage to forest stands, the so-called "New type of forest decline" began to appear in Europe in the 1970s, which manifested itself primarily in the yellowing of the assimilation apparatus, especially in Norway spruce (Picea abies [L.] Karst) (Vejre 1999; Van der Perre et al.2012). As a result, extensive experiments have been established with liming and fertilization of forest ecosystems and their impact on health status (Lomský et al. 2012; Vacek et al. 2019b). In recent years, instead of $\mathrm{SO}_{2}$ $-\mathrm{O}_{3}$ and $\mathrm{NO}_{\mathrm{x}}$ air pollutions have significantly affected forest stands (Vacek et al. 2017; Giovannelli et al. 2019; Mikulenka et al. 2020).

Through decades, it has been shown that fertilization as well as liming can be beneficial especially at early stages of stand development (overcoming transplant shock) (Berger \& Glatzel 2001; Kuneš et al. 2011). Fertilizing, and especially liming should be regarded as immediate help to improve the vitality of forest stands in a short period of time (Podrázský et al. 2005). Long-term cultivation is a question of appropriate silvicultural treatments, tree species composition, spatial and age structure (Remeš et al. 2015b; Švec et al. 2015; Štefančík et al. 2018; Sharma et al. 2019; Vacek et al. 2019a, 2019c). Reaching stability of forests is important under the conditions of ongoing climate change and large-scale forest disturbances (Kolář et al. 2017; Gallo et al. 2020; Vacek et al.2020b, 2021). Healthy forests are also a reservoir of natural resources in the age of different economic problems of societies (Trumbore et al. 2015; Gallo et al. 2018).

The review article summarizes results of the 48 research articles of fertilization, liming and nutrition in forest ecosystems published by authors at the Department of Silviculture of Faculty of Forestry and Wood Sciences in Prague in scientific journals over the past more than 20 years (Table 1 ). Forest fertilizing and liming are considered two more or less controversial and intensive interventions into forests (Podrázský 2006a; Ferreira et al. 2020). These activities are costly and therefore their effects need to be studied and evaluated in order to make qualified decision in critical situations (Podrázský 2006b). This review shows most important studies in terms of fertilizing and liming, just as it presents some alternatives of intensive care of emerging forest cultures and mature forest stands. The study area covers all forest vegetation ranges from lowland forests to the subalpine belt of grass vegetation including 11 Natural Forest Areas (Fig. 1). The review consists of 18 tree species, with the greatest emphasis on Norway spruce. The objective of this review was to summarize the main results of the studied research and to make recommendations and limits for forestry practices.

\section{Fertilizing in maturing stands and underplantings}

The extensive symptoms of Norway spruce yellowing were recorded in the late 1970s in the Śumava National Park (Kovářová \& Vacek 2003; Podrázský et al. 2003b), so the effect of slow release fertilizer was investigated in the maturing and mature forest stands (44-107 yrs). The aim of fertilization was to alleviate the symptoms of needle yellowing, which was probably caused by the deficiency of $\mathrm{Mg}$ in the naturally acidic and further acidified soils. Fertilizer named Silvamix Mg NPK was manually placed on the soil surface at a dose corresponding to the following hectare amount of pure nutrients: $100 \mathrm{~kg} \mathrm{~N}, 96.5 \mathrm{~kg} \mathrm{Mg}, 54 \mathrm{~kg} \mathrm{~K}, 57 \mathrm{~kg}$ P. After application, fertilization significantly increased the magnesium content (by more than $30 \%$ ) and base saturation in soils and decreased the amount of exchangeable aluminum and hydrolytic acidity. In the short term (after two years), the effect of fertilizer application on tree defoliation and yellowing symptoms was significantly positive, especially in case of weakened and supressed trees. Fertilization further promoted the growth of trees which persists even in the second decade after application, while positive effects lasted for a shorter time than the effect on foliage (Podrázský et al. 2002, 2003b, 2005; Vacek et al. 2006, 2009). During 15 years after fertilization, defoliation and yellowing decrease by $5 \%$ and $10 \%$ and radial growth increase by $15 \%$ (Vacek et al. 2019b).

Two experiments in the territory of the School Forest Enterprise in Kostelec nad Černými lesy (localities Aldašín and Krymlov) were based on analogous methods consisting of application of full (complex) fertilization and nitrogen fertilization in Norway spruce stands at the age of $70 \mathrm{yrs}$, based on the application of a complex fertilizer and nitrogen fertilizer. The applied hectare dose in the variant complex fertilizer (with balanced content of N, P, K, Ca) was as follows: $150-200 \mathrm{~kg}$ of pure N, 50-100 kg P, $100 \mathrm{~kg} \mathrm{K,} \mathrm{100-400} \mathrm{kg} \mathrm{Ca.} \mathrm{The} \mathrm{hectare} \mathrm{dose}$ used in the nitrogen fertilizer variant was $180-200 \mathrm{~kg} \mathrm{~N}$ in the form of ammonium nitrate. A positive response of complex fertilization to soil chemistry was registered even after 40 years after application, but unbalanced $\mathrm{N}-$ fertilization resulted in increased leaching of ions from the soil (Mg, Ca), thus contributing to acidification of the site. The volume production of the entire stand increased only slightly, more distinct differences can be seen on the individual tree level (Remeš \& Podrázský 2006; Podrázský 2006b; Remeš \& Podrázský 2009).

In the Babín locality (Ždárské vrchy), Norway spruce and Scots pine (Pinus sylvestris L.) dominated stand with individual admixture of white fir was underplanted using giant fir (Abies grandis [Douglas ex D. Don] Loudon) 
Table 1. Selection of the research articles of fertilization, liming and nutrition in forest ecosystems published by authors at the Department of Silviculture of Faculty of Forestry and Wood Sciences in Prague, study objectives (SP - soil parameters, HS health status including foliation and mortality, GR - growth rate, FN - foliar nutrients) and effect (positive, negative, both, no effect) on different species (see Notes).

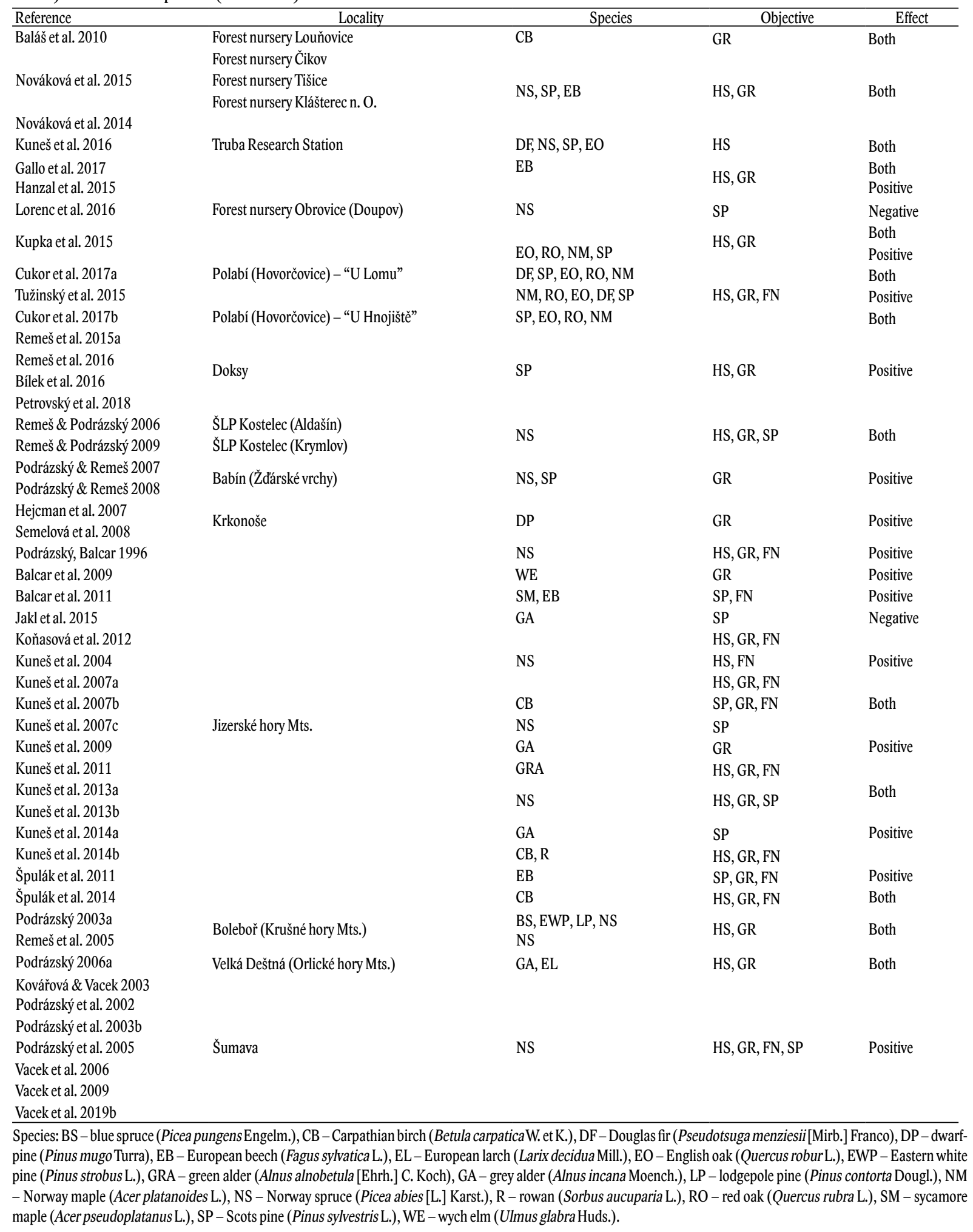




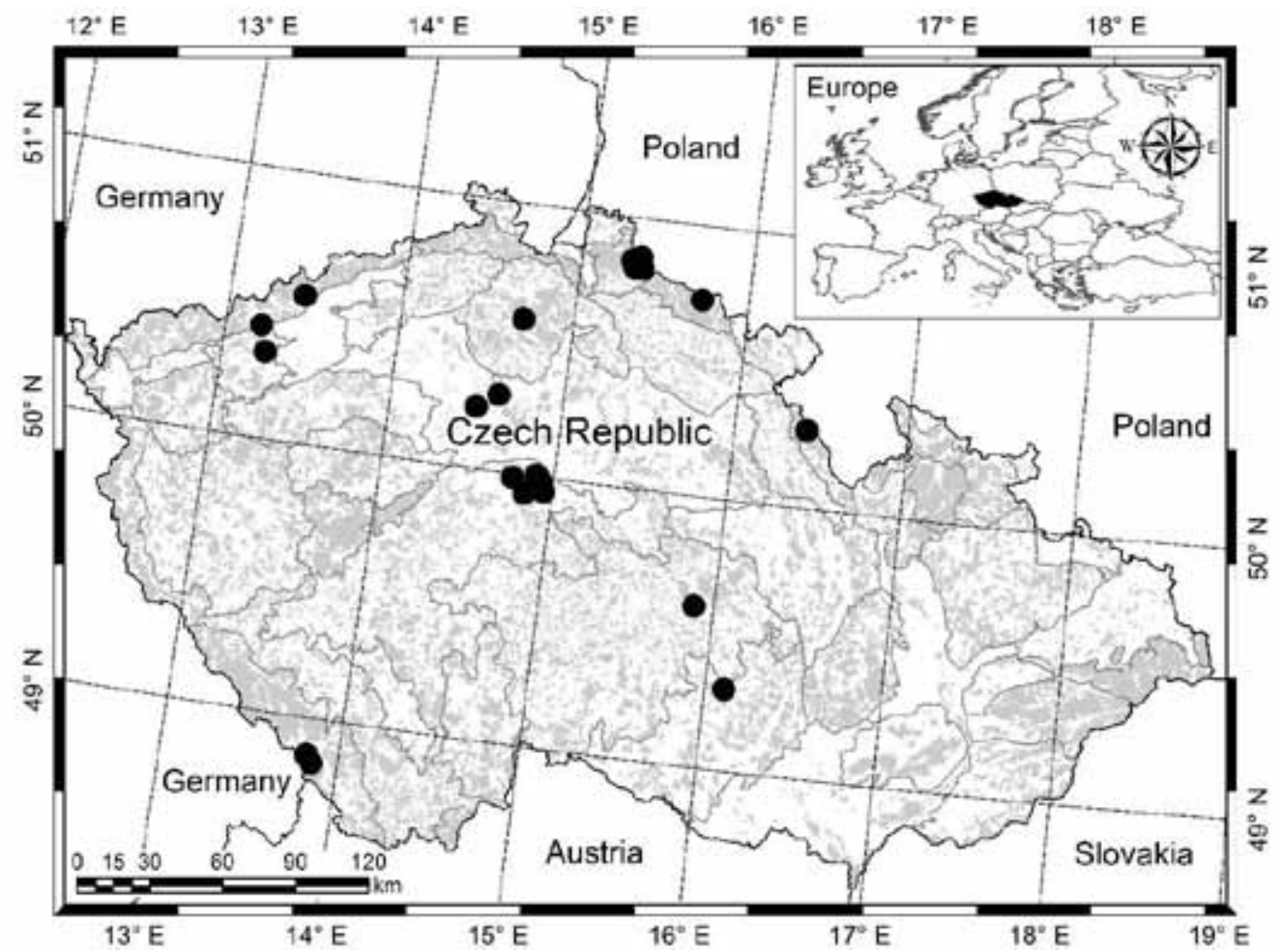

Fig. 1. Location of 24 study areas engaged in fertilization and liming research (black dots); gray lines showing separating Natural Forest Areas and gray dots forest cover in the Czech Republic.

(habitat 5K8, $580 \mathrm{~m}$ asl, soil type Dystric Cambisol). The underplantings were gradually released. In order to support the fir transplants, the application of Silvamix Forte fertilizer in the forms of tablets and powder was performed 6 years after outplanting, namely by fertilizers under the trade name Silvamix Forte ( 4 tablets of $10 \mathrm{~g}$ per transplant) and Silvamix MG fertilizers ( $40 \mathrm{~g}$ of powdered fertilizer per transplant). Markedly positive effect of fertilization on the height increment of giant fir transplants was observed already in the first year after application, with highest effect occurring 5 years after application. The effect of the tablet form was slightly higher, probably because of the higher nitrogen content. The application of fertilizer thus demonstrably increased the height increment of the underplanted transplants, which accelerated the growth of the trees under the influence of roe deer. After about 7 years, the effects of fertilization, manifested by increased growth, gradually disappeared, but the difference in the average height of transplants remains more than $1 \mathrm{~m}$ in favor of fertilized variants. The experiment confirmed that in the conditions of nutrient poor habitat, the application of slow release fertilizer can effectively support the growth performance of nutrient-demanding tree species (Podrázský \& Remeš 2007, 2008).

The effect of different uses of individual parts of tree biomass remaining after harvesting (chipping, burning, piling up vs. export of biomass out of habitat) on the nutrient cycle as well as on the growth of the next generation of Scots pine forest in Doksy were investigated. The most favourable growth performance was registered for transplants on the plots with the harvest residues crushed and dispersed. Treatments with the removal or burning of the residues were comparable (Remeš et al. 2015a, 2016). Growth of pine transplants was positively influenced by additional woody ash, with the greatest effect on poor habitats. The magnetic mapping method revealed that the dispersed ash remains on the surface and does not penetrate to deeper layers (Petrovský et al. 2018).

In order to understand the distribution of mineral nutrients in the individual parts of pines in rotation age, sample trees were analysed. The highest nutrient concentration was in needles, bark and wood branches. The lowest concentration was in trunk, but with a high weight (approx. 5 times) it exceeds the sum of the weight of all the other fractions. Therefore, it is desirable to limit the removal of debris on poor habitats to reduce soil depletion of mineral nutrients (Bílek et al. 2016).

\section{Use of fertilizers on afforestations of the clear-cuts caused by air-pollution}

The research facility was located in Boleboř (Ore Mts. Krušné hory) on a large clear-cut caused by air-pollution calamity in the 1980s. Before the reforestation, bulldozer soil preparation was performed. Different treatments of amelioration (2-phase full-area fertilizing) measures were implemented on individual sub-areas in combination with the planting of fallowing tree species: blue spruce (Picea pungens Engelm.), European larch (Larix 
decidua Mill.), lodgepole pine (Pinus contorta Dougl.), Eastern white pine (Pinus strobus L.), grey alder (Alnus incana Moench.) and European beech (Fagus sylvatica L.). The results show that chemical amelioration is registrable in soil chemistry even after 20 years by increased $\mathrm{pH}$, bases content, macroelements and saturation of the soil complex. The tree species composition has even greater influence on soil chemistry than amelioration measures (alder - influence was very positive vs. spruce and larch - negative), (Podrázský et al. 2003a).

Another Norway spruce plantation at the same locality was studied. This site was affected by spreading of windrows created by a previous bulldozer site preparation done before afforestation after the air-pollution forest decline. Three treatments of fertilization were performed: the complex fast-release fertilizer Cererit and the slow-release Silvamix fertilizer in powder and tablet form. The impact of Silvamix fertilization was evident in a very short time. It was manifested by a reduction in mortality (more than $2.3 \times$ lower in comparison to control) and a significant increase in plant growth. Silvamix fertilization also almost eliminated mortality and colour changes on leaves. On the contrary, the application of Cererit led to an unbalanced nutrition status (foliage discoloration), and a lower increment. Also particularly increased mortality was noted for the Cererit-fertilized treatment $(2.5 \times$ in comparison to control). Besides, a significant reduction in the nitrogen foliage content of the Cererit fertilized treatment, no consistent and significant changes of foliar chemistry were recorded (Remeš et al. 2005).

Experimental liming was done in the plantation of Norway spruce on mountain sites devastated by air pollution on the locality Velká Deštná (1,100 m asl, habitat 8Z2, soil type Histic Podzol), situated in the ridge part of Eagle Mts. (Orlické hory) (Podrázský 2006a). The area was established in 1988 in the then 4-year planting of Norway spruce. On partial plots $(10 \times 10 \mathrm{~m})$ a manual surface application of limestone crumb was performed in 4 variants $[0 ; 1,308 ; 2,826 ; 3,924$ and $8,478 \mathrm{~kg}$ of fine grains $(<1 \mathrm{~mm})$ per ha], combining coarsely and finely ground crumb and dose size 3 and $9 \mathrm{t} \mathrm{ha}^{-1}$. The aim of the experiment was to monitor for a long time the effect of different intensities of liming and coarseness of the crumb on soil chemistry and the growth of spruce cultures in the exposed mountain habitat. Some parameters of soil chemistry were positively adjusted (increase of $\mathrm{pH}$, base content and cation exchange capacity). The greatest effect was observed in the case of surface humus horizons about 10 years after application, in the case of deeper horizons $(\mathrm{H}, \mathrm{A})$ about 15 years after application. A positive effect on the growth of spruce plantings was recorded at lower doses of liming. The best growing variant (high dose, coarse crumb) had an average height of $178 \mathrm{~cm} 10$ years after application, compared to the control with a height of $146 \mathrm{~cm}$. However, growth depression was recorded on the strongest calcareous variant (high dose, fine pulp) - the average height was only $127 \mathrm{~cm}$.
Liming has adversely affected the acceleration of humus mineralization, which is associated with an increased risk of nutrient loss. During the observed period, there was a significant improvement in most soil characteristics in all variants. This was probably the result of a combination of favourable effects (reduction of emissions and coverage of the soil with grass turf with a more favourable fall), which demonstrates the considerable regenerative capacity of the soil (Podrázský 2006a).

Many of particular experiments focused on afforestation in harsh mountain condition were done around the Jizerka locality (Jizera Mts. - Jizerské hory), (Balcar \& Podrázský1994). Norway spruce plantation (Děčín town environs originated) was treated by dolomitic limestone on the surface and into the holes during planting. A positive effect on soil chemistry, growth and nutrient content in needles has been demonstrated. However, adverse effects on the nitrogen and phosphorus content of the soil were recorded (Podrázský \& Balcar 1996).

The analysis of sample trees was done in the same plantation. The limestone fertilizing boosted the growth of both aboveground and belowground biomass, while not limiting the growth of roots from the fertilized planting hole to the surrounding soil. The concentration of nutrient elements in biomass did not differ between the limed and control variant. Total amount of nutrient elements due to higher biomass volume was higher in the limed treatment. The distribution of elements in biomass followed the standard model - most in the needles, then bark and small branches, least in trunk wood (Kuneš et al. 2007a).

Subsequently, in the part of the plantation treated by spot-fertilization of limestone, the soil chemistry was evaluated in the fertilized hole and at a distance of $40 \mathrm{~cm}$ and $80 \mathrm{~cm}$ from the hole. Apparent evidence of soil chemistry change in the soil of the planting hole was observed, but only a minimal effect at a distance of $80 \mathrm{~cm}$ compared to control, taken outside the fertilized planting. Spot-fertilization is considered laborious, but sensitive method of fertilization, where almost no surrounding environment is affected, serving only to fertilize the target tree (Kuneš et al. 2006). In case of the surface liming treatment, the effect on soil chemistry was also studied. It was found to be positive but considering the large dose, it was a slight influence on soil chemistry. The limestone treatment contained less organic matter and nitrogen (Kuneš et al. 2007c).

Neighbouring Norway spruce plantation of the Giant Mts. (Krkonoše) origin was treated with crushed amphibolite and limestone placed in planting holes. After 15 years, the positive effect of fertilization on mortality and growth was found. The effect on foliage nutrient content was negligible. The control option had more nitrogen concentration, probably due to the support of microbial activity in the soil, leading to higher consumption of nitrogen (Koňasová et al. 2012). 
Norway spruce plantation of the Beskydy Mts. origin, fertilization of the amphibolite (surface) and Silvamix (tablets into the soil) was done during the outplanting. After 10 years, reduced mortality and higher content of most nutrients in needles was proved for fertilized treatments (Kuneš et al. 2004).

The evaluation of the same plantation 14 years after the planting showed significantly more biomass amount in the fertilized treatments. The absolute amount of nutrients bound to fertilized trees was therefore higher due to higher biomass, but the effect of both fertilization treatments on the nutrient concentration in the above-ground parts of the trees was insignificant. However, lower P and $\mathrm{N}$ concentrations were recorded in root biomass in fertilized treatments. The highest nutrients content was detected in the needles and bark, small branches. The lowest content has a trunk wood. Significant individual differences were found in both biomass and nutrient concentration (Kuneš et al. 2013b). In other study from the same planting, the growth was significantly higher for the Silvamix-fertilized treatment. In the amphibolite-fertilized treatment, the positive effect on growth was apparent but not conclusive. Unlike Silvamix, the decrease in mortality was seen in the amphibolite variant. Repeated foliage analyses have shown a gradual decrease in concentration of phosphorus, which is considered a potentially deficient element (Kuneš et al. 2013a).

Using DGT (diffusive gradient in thin film) units, heavy metals content in the soil were analysed for amphibolite treatments. There was a slight increase in the concentrations of some heavy metals in the soil in the fertilized treatment, the increase in the concentration of Al being more pronounced (Jakl et al. 2015).

The planting of grey alder established in 2000 was after 2 years fertilized with a mixture of crushed limestone and basalt with surface application. It was evaluated as 8-year old plantation, with a positive height increment reaction to fertilization. The effect on nutrient content in leaves was insignificant (Kuneš et al. 2009).

Nearby planting of grey alder established in 2003 was fertilized with a mixture of crushed amphibolite and limestone with spot and surface application. There was a significant impact on biomass growth and accumulation in both treatments (minimal differences between the fertilized treatments). The nutrient concentrations in different parts of trees were more or less the same between treatments (except for Mg, in particular). A slight change in the proportion of element content in different parts of trees was registered. In fertilized treatments, the biomass growth within stems was relatively higher than in leaves. Pioneer species often respond better than climax species. It is therefore beneficial to support pioneer species, which then efficiently transform fertilizer into a litterfall (Kuneš et al. 2014a).

In 2-year old plantation of green alder (Alnus alnobetula [Ehrh.] C. Koch), a surface application of a mixture of crushed limestone and basalt was performed. From the beginning, fertilization has a significant positive effect on growth. Later, fertilized treatment equalized with the control one. The positive effect of fertilization on mortality and a slight increase in Ca and Mg in leaves was noted. In the case of $\mathrm{P}$ and $\mathrm{N}$, the influence was not detected (Kuneš et al. 2011).

For plantings of European beech and sycamore (Acer pseudoplatanus $\mathrm{L}$.), when placing the crushed limestone into planting holes, the beneficial effect of liming on soil chemistry was still proven 15 years after planting. The influence on nutrient content in leaves was recorded only in $\mathrm{Ca}$, otherwise without evidence (Balcar et al. 2011). The same beech plantation was treated with crushed limestone during the planting. The evaluation was carried out in a 17-year-old stand. Apparent positive effect of fertilization on nutrient content in soil has been documented. However, the nutrient content of the leaves did not differ. The fertilized trees also showed an improvement of some measured parameters of chlorophyll fluorescence (Špulák et al. 2011).

Fertilization by the crusted limestone and amphibolite positively influenced the growth performance of wych elm (Ulmus glabra Huds.) plantation which substantially suffers from the harsh condition of this locality (Balcar et al. 2009).

During outplanting, plantation of the Carpathian birch (Betula carpatica W. et K.) was spot-fertilized with crushed limestone and basalt. Approximately 15 years after the planting, in the limestone variant a partial positive influence of soil chemistry (in $\mathrm{Mg}, \mathrm{Ca}$ ) was observed, but at the same time the leaching of N, P, K was registered. In the variant with basalt, the influence was similar but significantly lower. The content of foliage nutrients was not significantly affected by fertilization. Only in the case of Ca there was a higher content in the fertilized treatments (negative correlation with the growth). In terms of growth, the substantial growth retardation persisted in fertilized variants, probably due to the specific physiological properties of Carpathian birch, which requires nutritionally poor and acidic soil (Kuneš et al. 2007b).

The findings from the field study were verified under controlled conditions of the forest nursery. Seedlings of Carpathian birch were treated by combined different intensity of nitrogen fertilization (urea) with liming. Weak liming and fertilization with nitrogen fertilizer had rather positive effect on growth; simultaneously strong urea fertilization had a neutral but not negative effect. A markedly positive growth response was noted in a combination of strong urea fertilization and weak or null liming (Baláš et al. 2010).

In the bottom of Jizerka valley, the plantation of rowan (Sorbus aucuparia L.) was established in order to assess whether the large-sized or common-sized planting stock show better ability to overcome the stress from the late and early frost events, commonly occurring in this locality (Gallo et al. 2014). Additionally, the fertilization by the Silvamix tablets was applied. The large-sized planting stock showed better growth performance and 
lower damage from the frost events and from the snow pressure. However, fertilization did affect neither growth nor the foliage chemistry (Kuneš et al. 2014b).

Plantation of the Carpathian birch in the same location was established in 2008-9, the primary objective of which was to test the capacity of the Carpathian birch to survive and grow in one of the most extreme frost-stressed locations in the Czech Republic. Oneyear after planting it was fertilized with surface fertilizers - control treatment and treatments with an increased content of phosphorus and a treatment with a balanced composition of the elements were included. Already 2 years after application, a significantly higher content of phosphorus in leaves was found, but it exhibited worse chlorophyll fluorescence parameters. The Carpathian birch plantation was compared with 17-year-old planting of Carpathian birch on the side ridge on the former air-polluted clear-cut area (placing crushed limestone into holes during outplanting). In the fertilized treatment, there were still higher concentrations of nutrients in the leaves. However, the fertilized treatment exhibited significantly worse increment (Špulák et al. 2014).

\section{Experiments with long-term fertilization of subalpine grasslands}

The effect of fertilization was also investigated in the dwarf-pine (Pinus mugo Turra) vegetation zone on subalpine grasslands in the Giant Mountains, where Ca $\left(20-2,130 \mathrm{~kg} \mathrm{ha}^{-1}\right), \mathrm{N}\left(50-500 \mathrm{~kg} \mathrm{ha}^{-1}\right), \mathrm{P}(0$ $\left.240 \mathrm{~kg} \mathrm{ha}^{-1}\right)$ and $\mathrm{S}\left(0-300 \mathrm{~kg} \mathrm{ha}^{-1}\right)$ fertilizers were applied between 1965 and 1967 . Following variants of fertilizers were used: $\mathrm{CaSO}_{4}+\mathrm{Ca}\left[\mathrm{H}_{2} \mathrm{PO}_{4}\right]_{2}, \mathrm{NH}_{4} \mathrm{NO}_{3}+\mathrm{CaCO}_{3}$ and $\mathrm{CaO}$. In 2004, the effect of all fertilizer applications on the stand structure was still evident 37 years after the last fertilizer application. Avenella flexuosa and Anthoxanthum alpinum were the dominant species on phosphorusfertilized plots, while Nardus stricta was the dominant species on control plots even after $\mathrm{Ca}$ and $\mathrm{N}$ application. Anthoxanthum alpinum biomass production was higher in all fertilized variants than in the control. Total standing biomass as well as dead biomass and sward height were lowest on plots fertilized with P (Hejcman et al. 2007).

The grassland called "Grass Garden" on the subalpine meadow in the Giant Mountains has been fertilized for more than 200 years with ash from Norway spruce and dwarf pine. Mean annual doses of applied nutrients per hectare calculated from the number of kept animals and volume of burned firewood in sub-alpine grassland were 90-140 kg N, 250-350 kg K, 30-50 kg P, 300-450 kg Ca, 80-130 kg Mg. After 62 years, Deschampsia caespitosa and Avenella flexuosa significantly dominated the fertilized areas, while Nardus stricta dominated the unfertilized areas. The Ca concentration in the soil was more than twice as high in the fertilized variants as in the control, which suggests that it was very difficult to deplete the applied Ca even on extreme podzol soils and under climatic conditions of the subalpine vegetation stage. The concentrations of $\mathrm{Mg}$ and $\mathrm{P}$ and the $\mathrm{N}$ : P ratio were significantly affected in the aboveground plant biomass of the fertilized variants (Semelová et al. 2008).

\section{Other enhancing substances (non-fertilizers)}

Alginite is a rock of fossilized algae and it can serve as soil conditioner to hold water in the soil. Eco-fertilizer alginite used in the studies had following content of macroelements: Ca 15,528 $\mathrm{mg} \mathrm{kg}^{-1}, \mathrm{Mg} 1,841 \mathrm{mg} \mathrm{kg}^{-1}$, $\mathrm{P} 43 \mathrm{mg} \mathrm{kg}^{-1}, \mathrm{~K} 196 \mathrm{mg} \mathrm{kg}^{-1}$ and $\mathrm{N}$ total content was $0.207 \%$. The influence of alginite application on growth of forest trees is very ambiguous. The impact was evaluated on growth parameters (height increment, mortality and foliar nutrient content) of Douglas fir (Pseudotsuga menziesii [Mirb.] Franco), Scots pine, English oak (Quercus robur L.), red oak (Quercus rubra L.) and Norway maple (Acer platanoides L.) seedlings on former agricultural land near Hovorčovice in the Polabí region under warm and dry climate. Two variants with the application of $0.5 \mathrm{~kg}$ and $1.5 \mathrm{~kg}$ of alginite per planting point were planted. There was a slight positive effect on pine growth and mortality but only in the first year. In following seasons, however, mortality has increased. Slightly positive results were recorded in maple and red oak (Kupka et al. 2015; Tužinský et al. 2015; Cukor et al. 2017c). In terms of growth, the application of alginite had a slightly positive effect, but rather in the following years after planting (in the first years it was rather negative). The influence of alginite on the nutrient content of the assimilation apparatus was neutral to slightly positive (mostly slightly higher content of $\mathrm{N}, \mathrm{P}, \mathrm{Ca}, \mathrm{Mg}$ ), (Kupka et al.2015; Cukor et al. 2017a). The unconvincing results of the alginite application seem to be related to its essential characteristic, the ability to bind water. This is, on one hand, a positive effect (slower drying, more available water for plants), on the other hand, in a longer dry season, the alginite-enriched soil needs more water to increase moisture to a level that is available for roots.

Positive effect of bio-algeen stimulator (liquid or gel of algae extract) on the growth of Norway spruce seedlings in a forest nursery (Hanzal et al. 2015) was registered, but a suppression of the active mycorrhiza emerged (Lorenc et al. 2016).

The phytohormones brassinosteroids should help plants overcome stress conditions like drought. The effect of application by spraying on seedlings in the forest nursery was studied. In Scots pine nursery plantation, there was a decrease in mortality, but also decrease in growth. In nursery Norway spruce plantation, the results were ambiguous and inconsistent (Nováková et al. 2015). In the case of plantation established on abandoned agricultural land in the locality of Truba (Kostelec nad Černými 
lesy), a positive effect on mortality was observed in the European beech plantation (Gallo et al. 2017). On the contrary, in the same locality, the effect on mortality and growth performance of Scots pine plantation was significantly negative (Nováková et al. 2014). Furthermore, the effect of brassinosteroids in overcoming stress during germination was investigated. The results were again quite inconsistent. A slight positive effect was observed on Norway spruce seeds, while it was negative for Douglas fir (Kuneš et al. 2016). The published results show that the effect of brassinosteroids is mostly apparent but is significantly different for individual species and application methods.

\section{Conclusion}

Forest fertilization has great potential to increase productivity of forest biomass, decrease risks, and strengthen sustainability production. Fertilizers mostly showed a positive effect on the forest growth and mortality rate. The use of fertilizers was detected by the soil analysis sometimes after decades of application. Only in a minority of cases was fertilization reflected in the biomass of the trees. Well-designed fertilization can be beneficial especially at early stages of stand development (overcoming planting shock). Spot-applied fertilizing with a slow release fertilizer (preferably in the form of tablets) is effective in comparison to brassinosteroids and alginite with inconsistent results. However, artificial fertilization is to be considered as a means of helping to long-term improve the vitality of the forest in a short period of time. In particular, middle-aged spruce stands with marked symptoms of yellowing can be grown to a harvest age after a suitably selected application of fertilization. This may become more important in the light of the air pollution and ongoing climate change in relation to drought, weather extremes and infestation by secondary pathogens (especially bark beetles). However, it is necessary to achieve the optimization of the fertilization process to provide a high rate of economic return in terms of increased biomass production for owners.

In the stands of younger and middle age, the cooperation of the process of fertilization and thinning of forest stands is very important. The long-term quality cultivation is a question of appropriate species composition, genetic properties, spatial and age structure. On the other hand, the possible environmental and economic risks of fertilization should be also taken into account and more research is needed on the effects of fertilizers on the stand level and the landscape level. Moreover, further longterm and complex research on resource use efficiency, wood quality, root development, mycorrhiza systems, ground vegetation, water quality and resistance to abiotic stresses in relation to fertilization is also necessary.

\section{Acknowledgements}

The study was supported by the Ministry of Agriculture of the Czech Republic (projects No. QK1910232 and QK1920328) and by the GS L $\check{C} R$ (No. 85). The article was elaborated using the facilities at Truba Research Station in Kostelec nad Černými lesy (Department of Silviculture, Faculty of Forestry and Wood Sciences, Czech University of Life Sciences).

\section{References}

Albaugh, T. J., Fox, T. R., Cook, R. L., Raymond, J. E., Rubilar, R. A., Campoe, O. C., 2019: Forest fertilizer applications in the southeastern United States from 1969 to 2016. Forest Science, 65:355-362.

Baláš, M., Kuneš, I., Zahradník, D., 2010: Reakce břízy karpatské na vápnění a přihnojení dusíkem. Zprávy lesnického výzkumu, 55:106-114.

Balcar, V., Podrázský, V., 1994: Založení výsadbového pokusu v hřebenové partii Jizerských hor.Zprávylesnického výzkumu, 39:1-7.

Balcar, V., Kacálek, D., Kuneš, I., 2009: Vývoj kultury jilmu horského (Ulmus glabra Huds.) v hřebenové poloze Jizerských hor. Zprávy lesnického výzkumu, 54:3-8.

Balcar, V., Kacálek, D., Kuneš, I., Dušek, D., 2011: Effect of soil liming on European beech (Fagus sylvatica L.) and sycamore maple (Acerpseudoplatanus L.) plantations. Folia Forestalia Polonica, series A - Forestry, 53:85-92.

Baum, C., Makeschin, F., 2000: Effects of nitrogen and phosphorus fertilization on mycorrhizal formation of two poplar clones (Populus trichocarpa and $P$. tremula $\mathrm{x}$ tremuloides). Journal of Plant Nutrition and Soil Science, 163:491-497.

Berger, T. W., Glatzel, G., 2001: Response of Quercus petraea seedlings to nitrogen fertilization. Forest Ecology and Management, 149:1-14.

Bílek, L., Remeš, J., Fulín, M., Chalupová, T., Procházka, J., 2016: Množství a distribuce nadzemní biomasy borovice lesní v oblasti přirozených borů. Zprávy lesnického výzkumu, 61:108-114.

Cukor, J., Linhart, L., Vacek, Z., Baláš, M., Linda, R., 2017a: The effects of Alginite fertilization on selected tree species seedlings performance on afforested agricultural lands. Central European Forestry Journal, 63:48-56.

Cukor, J., Vacek, Z., Linda, R., Bílek, L., 2017b: Carbon sequestration in soil following afforestation of former agricultural land in the Czech Republic. Central European Forestry Journal, 63:97-104.

Cukor, J., Vacek, Z., Linda, R., Remeš, J., Bílek, L., Sharma, R. et al., 2017c: Effect of mineral eco-fertilizer on growth and mortality of young afforestations. Austrian Journal of Forest Science, 134:367-386. 
Cukor, J., Vacek, Z., Linda, R., Vacek, S., Marada, P., Šimůnek, V., Havránek, F., 2019: Effects of bark stripping on timber production and structure of Norway spruce forests in relation to climatic factors. Forests, 10:320.

Cukor, J., Zeidler, A., Vacek, Z., Vacek, S., Šimůnek, V., Gallo, J., 2020: Comparison of growth and wood quality of Norway spruce and European larch: effect of previous land use. European Journal of Forest Research, 139:459-472.

Čermák, P., Glogar, J., Jankovský, L., 2004: Damage by deer barking and browsing and subsequent rots in Norway spruce stands of Forest Range Mořkov, Forest District Frenštát p. R. (the Beskids Protected Landscape Area). Journal of Forest Science, 50:2430.

Daioglou, V., Doelman, J. C., Wicke, B., Faaij, A., van Vuuren, D. P., 2019: Integrated assessment of biomass supply and demand in climate change mitigation scenarios. Global Environmental Change, 54:88-101.

Dobor, L., Hlásny, T., Rammer, W., Zimová, S., Barka, I., Seidl, R., 2020: Is salvage logging effectively dampening bark beetle outbreaks and preserving forest carbon stocks? Journal of Applied Ecology, 57:67-76.

Ferreira, G. W., Rau, B. M., Aubrey, D. P., 2020: Herbicide, fertilization, and planting density effects on intensively managed loblolly pine early stand development. Forest Ecology and Management, 472:118206.

Fox, T. R., LeeAllen, H., Albaugh, T. J., Rubilar, R., Carlson, C. A., 2007: Tree nutrition and forest fertilization of pine plantations in the southern United States. Southern Journal of Applied Forestry, 31:5-11.

Gallo, J., Kuneš, I., Baláš, M., Nováková, O., Drury, M. L., 2014: Occurrence of frost episodes and their dynamics in height gradient above the ground in the Jizerské hory Mts. Journal of Forest Science, 60:35-41.

Gallo, J., Baláš, M., Linda, R., Kuneš, I., 2017: Growth performance and resistance to ground late frosts of Fagus sylvatica L. plantation treated with a brassinosteroid compound. Journal of Forest Science, 63:117-125.

Gallo, J., Kuneš, I., Baláš, M., 2018: Contribution of reforestation using saplings to conservation of forest ecosystems. Wildlanka, 6:100-107.

Gallo, J., Baláš, M., Linda, R., Kuneš, I., 2020: The effects of planting stock size and weeding on survival and growth of small-leaved lime under drought-heat stress in the Czech Republic. Austrian Journal of Forest Science, 137:43-66.

Giovannelli, A., Traversi, M. L., Anichini, M., Hoshika, Y., Fares, S., Paoletti, E., 2019. Effect of long-term vs. short-term ambient ozone exposure on radial stem growth, sap flux and xylem morphology of O3-sensitive poplar trees. Forests, 10:396.
Hanzal, V., Janiszewski, P., Kubeček, J., Bergman, J., Gjurov, V., Tužinský, M. et al., 2015: Support of the growth and prosperity of the Norway spruce (Picea abies) seedlings in forest nursery by the Bio-Algeen system - preliminary results. Polish Journal of Natural Sciences, 30:217-224.

Hedwall, P. O., Gong, P., Ingerslev, M., Bergh, J., 2014: Fertilization in northern forests-biological, economic and environmental constraints and possibilities. Scandinavian Journal of Forest Research, 29:301-311.

Hejcman, M., Klaudisová, M., Štursa, J., Pavlů, V., Schellberg, J., Hejcmanová, P. et al., 2007: Revisiting a 37 yeas abandoned fertilizer experiment on Nardus grassland in the Czech Republic. Agriculture, Ecosystems and Envirionment, 118:231-236.

Jakl, M., Jaklová Dytrtová, J., Kuneš, I., Baláš, M., 2015: Effective concentration of elements in root zone of Norway spruce stand 16 years after fertilization probed with DGT. Water Air and Soil Pollution, 226:10.

Klavina, D., Pennanen, T., Gaitnieks, T., Velmala, S., Lazdins, A., Lazdina, D. et al., 2016: The ectomycorrhizal community of conifer stands on peat soils 12 years after fertilization with wood ash. Mycorrhiza, 26:153-160.

Kolář, T., Čermák, P., Trnka, M., Žid, T., Rybníček, M., 2017: Temporal changes in the climate sensitivity of Norway spruce and European beech along an elevation gradient in Central Europe. Agricultural and Forest Meteorology, 239:24-33.

Koňasová, T., Kuneš, I., Baláš, M., Millerová, K., Balcar, V., Špulák, O. et al., 2012: Influence of limestone and amphibolite application on growth of Picea abies L. plantation under mountain conditions. Journal of Forest Science, 58:492-502.

Kovářová, M., Vacek, S., 2003: Mountain Norway spruce forests: needle supply and its nutrient content. Journal of Forest Science, 49:327-332.

Král, J., Vacek, S., Vacek, Z., Putalová, T., Bulušek, D., Štefančík, I., 2015: Structure, development and health status of spruce forests affected by air pollution in the western Krkonoše Mts. in 1979-2014. Central European Forestry Journal, 61:175-187.

Králíček, I., Vacek, Z., Vacek, S., Remeš, J., Bulušek, D., Král, J. et al., 2017: Dynamics and structure of mountain autochthonous spruce-beech forests: impact of hilltop phenomenon, air pollutants and climate. Dendrobiology, 77:119-137.

Kuneš, I., Balcar, V., Čížek, M., 2004: Influence of amphibolite powder and Silvamix fertiliser on Norway spruce plantation in conditions of air polluted mountains. Journal of Forest Science, 50:366-373. 
Kuneš, I., Balcar, V., Vykypělová, E., Zadina, J., 2006: Vliv jamkové aplikace moučky dolomitického vápence na půdní prostředí uvnitř sadebních jamek a mimo jamkový prostor v rámci podmínek kyselého horského stanovištěv Jizerských horách. Zprávy lesnického výzkumu, 51:82-90.

Kuneš, I., Balcar, V., Vykypělová, E., Zadina, J., Šedlbauerová, J., Zahradník, D., 2007a: Vliv jamkové a pomístné povrchové aplikace dolomitického vápence na množství a chemické složení biomasy smrku ztepilého v Jizerských horách. Zprávy lesnického výzkumu, 52:316-315.

Kuneš, I., Balcar, V., Zahradník, D., 2007b: Influence of a planting hole application of dolomitic limestone powder and basalt grit on the growth of Carpathian birch (Betula carpatica W. et K.) and soil chemistry in the air-polluted Jizerské hory Mts. Journal of Forest Science, 53:505-515.

Kuneš, I., Balcar, V., Zahradník, D., 2007c: Vliv cílené povrchové aplikace dolomitického vápence na pedochemické parametry půdy na imisní holině ve vrcholových partiích Jizerských hor. Zprávy lesnického výzkumu, 52:234-245.

Kuneš, I., Balcar, V., Benešová, T., Baláš, M., Zadina, J., Zahradník, D. et al., 2009: Influence of pulverized limestone and amphibolite mixture on the growth performance of Alnus incana (L.) Moench plantation on an acidified mountain site. Journal of Forest Science, 55:469-476.

Kuneš, I., Koňasová, T., Balcar, V., Baláš, M., Zahradník, D., Kacálek, D. et al., 2011: Growth response of Alnus viridis to application of crushed limestone and amphibolite and forestry potential of the species in harsh acidic mountain sites. Journal of Forest Science, 57:200-209.

Kuneš, I., Baláš, M., Balcar, V., Kacálek, D., Millerová, K., Jančová, A. et al., 2013a: Effects of fertilisation on growth and nutrition of Norway spruce on a harsh mountain site. Journal of Forest Science, 59:306-318.

Kuneš, I., Zahradník, D., Balcar, V., Špulák, O., Baláš, M., Koňasová, T. et al., 2013b: Effects of fertilisation on biomass of Norway spruce on harsh mountain site. Journal of Forest Science, 59:8-21.

Kuneš, I., Baláš, M., Koňasová, T., Špulák, O., Balcar, V., Millerová, K. et al., 2014a: Biomass of speckled alder on an air-polluted mountain site and its response to fertilization. Environmental Management, 54:14211433.

Kuneš, I., Baláš, M., Zahradník, D., Nováková, O., Gallo, J., Nárovcová, J. et al., 2014b: Role of planting stock size and fertilizing in initial growth performance of rowan (Sorbus aucuparia L.) reforestation in a mountain frost hollow. Forest Systems, 23:273-287.

Kuneš, I., Baláš, M., Linda, R., Gallo, J., Nováková, O., 2016: Effects of brassinosteroid application on seed germination of Norway spruce, Scots pine, Douglas fir and English oak. iForest - Biogeosciences and Forestry, 10:121-127.
Kupka, I., Prknová, H., Holubík, O., Tužinský, M., 2015: Účinek př́pravků na bázi řas na ujímavost a odrůstání výsadeb lesních dřevin. Zprávy lesnického výzkumu, 60:24-28.

Law, B. E., Hudiburg, T. W., Berner, L. T., Kent, J. J., Buotte, P. C., Harmon, M. E., 2018: Land use strategies to mitigate climate change in carbon dense temperate forests. Proceedings of the National Academy of Sciences, 115:3663-3668.

Lindkvist, A., Kardell, Ö., Nordlund, C., 2011: Intensive forestry as progress or decay? An analysis of the debate about forest fertilization in Sweden, 19602010. Forests, 2:112-146.

Lomský, B., Šrámek, V., Novotný, R., 2012: Changes in the air pollution load in the Jizera Mts.: effects on the health status and mineral nutrition of the young Norway spruce stands. European Journal of Forest Research, 131:757-771.

Lorenc, F., Pešková, V., Modlinger, R., Podrázský, V., Baláš, M., Kleinová, D., 2016: Effect of Bio-Algeen ${ }^{\circledR}$ preparation on growth and mycorrhizal characteristics of Norway spruce seedlings. Journal of Forest Science, 62:285-291.

Mäkinen, H., Saranpää, P., Linder, S., 2002: Wood-density variation of Norway spruce in relation to nutrient optimization and fibre dimensions. Canadian Journal of Forest Research, 32:185-194.

Małek S, Belyazid S, Sverdrup H., 2012: Modelling changes in forest soil chemistry in the oldest spruce stands in the Potok Dupnianski Catchment in Southern Poland using ForSAFE model. Folia Forestalia Polonica, Series A, 54:209-214.

Marland, G., Obersteiner, M., 2008: Large-scale biomass for energy, with considerations and cautions: An editorial comment. Climatic Change, 87:335-342.

Mikulenka, P., Prokůpková, A., Vacek, Z., Vacek, S., Bulušek, D., Simon, J. et al., 2020: Effect of climate and air pollution on radial growth of mixed forests: Abies alba Mill. vs. Picea abies (L.) Karst. Central European Forestry Journal, 66:23-36.

Nováková, O., Kuneš, I., Gallo, J., Baláš, M., 2014: Effects of brassinosteroids on prosperity of Scots pine seedlings. Journal of Forest Science, 60:388-393.

Nováková, O., Gallo, J., Baláš, M., Špulák, O., Kuneš, I., 2015: Vliv brassinosteroidů na výškový př́růst, fluorescenci chlorofylu a mortalitu sazenic smrku ztepilého a borovice lesní v podmínkách lesní školky. Zprávy lesnického výzkumu, 60:122-129.

Petaja, G., Okmanis, M., Makovskis, K., Lazdina, D., Lazdins, A., 2018. Forest fertilization: economic effect and impact on GHG emissions in Latvia. Baltic Forestry, 24:9-16.

Petrovský, E., Remeš, J., Kapička, A., Podrázský, V., Grison, H., Borůvka, L., 2018: Magnetic mapping of distribution of wood ash used for fertilization of forest soil. Science of the Total Environment, 626:228-234. 
Podrázský, V., Balcar, V., 1996: Liming of spruce plantation on the top locality of the Jizerské Mts. Scientia Agriculturae Bohemica, 27:271-282.

Podrázský, V., Vacek, S., Ulbrichová, I., 2002: Vliv cíleného přihnojení na stav asimilačních orgánů smrku ztepilého s projevy žloutnutí. Zprávy lesnického výzkumu, 47:131-134.

Podrázský, V., Remeš, J., Ulbrichová, I., 2003a: Biological and chemical amelioration effects on the localities degraded by bulldozer site preparation in the Ore Mts. - Czech Republic. Journal of Forest Science, 49:141-147.

Podrázský, V., Vacek, S., Ulbrichová, I., 2003b: Effect of fertilisation on Norway spruce needles. Journal of Forest Science, 49:321-326.

Podrázský, V., Vacek, S., Remeš, J., Ulbrichová, I., 2005: Application of Mg-fertilizers to prevent and to decrease Norway spruce yellowing. Journal of Forest Science, 51:43-48.

Podrázský, V., 2006a: Effect of controlled liming on the soil chemistry on the immission clear-cut. Journal of Forest Science, 52:28-34.

Podrázský, V., 2006b: Fertilization as an ameliorative measure - examples of the research at the Faculty of Forestry and Environment. Journal of Forest Science, 52:58-64.

Podrázský, V., Remeš, J., 2007: Fertilization effect on the Grand fir plantations. Scientia Agriculturae Bohemica, 38:198-201.

Podrázský, V., Remeš, J., 2008: Vliv přihnojení na růst kultury jedle obrovské. Zprávy lesnického výzkumu, 53:207-210.

Podrázský, V., Vacek, Z., Vacek, S., Vítámvás, J., Gallo, J., Prokůpková, A. et al., 2020: Production potential and structural variability of pine stands in the Czech Republic: Scots pine (Pinus sylvestris L.) vs. introduced pines-case study and problem review. Journal of Forest Science, 66:197-207.

Prokůpková, A., Vacek, Z., Vacek, S., Blažejová, J., Schwarz, O., Bulušek, D., 2020: Dynamika přirozené obnovy horských lesů po větrné kalamitě: modelová studie pro Krkonoše. Zprávy lesnického výzkumu, 65:72-81.

Putalová, T., Vacek, Z., Vacek, S., Štefančík, I., Bulušek, D., Král, J., 2019: Tree-ring widths as an indicator of air pollution stress and climate conditions in different Norway spruce forest stands in the Krkonoše Mts. Central European Forestry Journal, 65:21-33.

Remeš, J., Podrázský, V., Ulbrichová, I., Meduna, V., 2005: Fertilization of Norway spruce plantations on the bulldozer-spread windrows in the Ore Mts. Journal of Forest Science, 51:49-53.

Remeš, J., Podrázský, V., 2006: Fertilization of spruce monocultures in the territory of Training Forest Enterprise in Kostelec nad Černými lesy. Journal of Forest Science, 52:73-78.
Remeš, J., Podrázský, V., 2009: Practice fertilization and state of humus forms in the area of the School Training Forest Kostelec nad Černými lesy - the Moštice locality. Ekológia (Bratislava), 28:74-81.

Remeš, J., Bílek, L., Fulín, M., 2015a: Vliv zpracování těžebních zbytků a následné mechanické přípravy půdy na chemické vlastnosti půd přirozených borů. Zprávy lesnického výzkumu, 60:138-146.

Remeš, J., Bílek, L., Novák, J., Vacek, Z., Vacek, S., Putalová, T., Koubek, L., 2015b: Diameter increment of beech in relation to social position of trees, climate characteristics and thinning intensity. Journal of Forest Science, 61:456-464.

Remeš, J., Bílek, L., Jahoda, M., 2016:Vliv přípravy půdy a hnojení dřevěným popelem na růst sazenic borovice lesní. Zprávy lesnického výzkumu, 61:197-202.

Saarsalmi, A., Mälkönen, E., 2001: Forest fertilization research in Finland: a literature review. Scandinavian Journal of Forest Research, 16:514-535.

Sharma, R. P., Štefančík, I., Vacek, Z., Vacek, S., 2019: Generalized nonlinear mixed-effects individual tree diameter increment models for beech forests in Slovakia. Forests, 10:451.

Semelová, V., Hejcman, M., Pavlů, V., Vacek, S., Podrázský, V., 2008: The Grass Garden in the Giant Mts. (Czech Republic): Residual effect of long-term fertilization after 62 years. Agriculture, Ecosystems and Environment, 123:337-342.

Smethurst, P. J., 2010: Forest fertilization: trends in knowledge and practice compared to agriculture. Plant and Soil, 335:83-100.

Smith, P., Powlson, D. S., Smith, J. U., Falloon, P., Coleman, K., 2000: Meeting Europe's climate change commitments: quantitative estimates of the potential for carbon mitigation by agriculture. Global Change Biology, 6:525-539.

Strengbom, J., Nordin, A., 2008: Commercial forest fertilization causes long-term residual effects in ground vegetation of boreal forests. Forest Ecology and Management, 256:2175-2181.

Šimůnek, V., Vacek, Z., Vacek, S., 2020: Solar Cycles in Salvage Logging: National Data from the Czech Republic Confirm Significant Correlation. Forests, 11:973.

Špulák, O., Vítámvás, J., Kacálek, D., Kuneš, I., 2011: Fluorescence chlorofylu, chemismus a obsah fotosynteticky aktivních pigmentů u listů buků vápněných do jamky. Zprávy lesnického výzkumu, 56:301-309.

Špulák, O., Martincová, J., Vítámvás, J., Kuneš, I. 2014: The effect of fertilization on chlorophyll activity, content of photosynthetically active pigments and nutrients in Carpathian birch leaves. Austrian Journal of Forest Science, 131:23-44.

Štefančík, I., Vacek, Z., Sharma, R. P., Vacek, S., Rösslová, M., 2018: Effect of thinning regimes on growth and development of crop trees in Fagus sylvatica stands of Central Europe over fifty years. Dendrobiology, 79:141-155. 
Švec, O., Bílek, L., Remeš, J., Vacek, Z., 2015: Analysis of operational approach during forest transformation in Klokočná Range, Central Bohemia. Journal of Forest Science, 61:148-155.

Toth, D., Maitah, M., Maitah, K., Jarolínová, V., 2020: The impacts of calamity logging on the development of spruce wood prices in Czech forestry. Forests, 11:283.

Trumbore, S., Brando, P., Hartmann, H., 2015: Forest health and global change. Science, 349:814-818.

Tužinský, M., Kupka, I., Podrázský, V., Prknová, H., 2015: Influence of the mineral rock alginite on survival rate and re-growth of selected tree species on agricultural land. Journal of Forest Science, 61:399_ 405.

Vacek, S., Podrázský, V., Hejcman, M., Remeš, J., 2006: Effect of Mg fertilization on yellowing disease of Norway spruce at higher elevations of the Šumava Mts., Czech Republic. Journal of Forest Science, 52:474-481.

Vacek, S., Hejcman, M., Semelová, V., Remeš, J., Podrázský, V., 2009: Effect of soil chemical properties on growth, foliation and nutrition of Norway spruce stand affected by yellowing in the Bohemian Forest Mts., Czech Republic. European Journal of Forest Research, 128:367-375.

Vacek, S., Vacek, Z., Remeš, J., Bílek, L., Hůnová, I., Bulušek, D. et al., 2017: Sensitivity of unmanaged relict pine forest in the Czech Republic to climate change and air pollution. Trees, 31:1599-1617.

Vacek, S., Prokůpková, A., Vacek, Z., Bulušek, D., Šimůnek, V., Králíček, I. et al., 2019a: Growth response of mixed beech forests to climate change, various management and game pressure in Central Europe. Journal of Forest Science, 65:331-345.

Vacek, S., Vacek, Z., Ulbrichová, I., Remeš, J., Podrázský, V., Vach, M. et al., 2019b: The effects of fertilization on the health status, nutrition and growth of Norway spruce forests with yellowing symptoms. Scandinavian Journal of Forest Research, 34:267-281.
Vacek, Z., Vacek, S., Slanař, J., Bílek, L., Bulušek, D., Štefančík, I. et al., 2019c: Adaption of Norway spruce and European beech forests under climate change: from resistance to close-to-nature silviculture. Central European Forestry Journal, 65:129-144.

Vacek, Z., Cukor, J., Linda, R., Vacek, S., Šimůnek, V., Brichta, J. et al., 2020a: Bark stripping, the crucial factor affecting stem rot development and timber production of Norway spruce forests in Central Europe. Forest Ecology and Management, 474:118360.

Vacek, Z., Prokůpková, A., Vacek, S., Cukor, J., Bílek, L., Gallo, J. et al., 2020b: Silviculture as a tool to support stability and diversity of forests under climate change: study from Krkonoše Mountains. Central European Forestry Journal, 66:116-129.

Vacek, Z., Vacek, S., Prokůpková, A., Bulušek, D., Podrázský, V., Hůnová, I. et al., 2020c: Long-term effect of climate and air pollution on health status and growth of Picea abies (L.) Karst. peaty forests in the Black Triangle region. Dendrobiology, 83:1-19.

Vacek, Z., Linda, R., Cukor, J., Vacek, S., Šimůnek, V., Gallo, J. et al., 2021: Scots pine (Pinus sylvestris L.), the suitable pioneer species for afforestation of reclamation sites? Forest Ecology and Management, 485:118951.

Van der Perre, R., Jonard, M., André, F., Nys, C., Legout, A., Ponette, Q., 2012: Liming effect on radial growth depends on time since application and on climate in Norway spruce stands. Forest Ecology and Management, 281:59-67.

Vejre, H., 1999: Stability of Norway spruce plantations in western Denmark - soil nutrient aspects. Forest Ecology and Management, 114:45-54.

Williams, D. R., Potts, B. M., Smethurst, P. J., 2003: Promotion of flowering in Eucalyptus nitens by paclobutrazol was enhanced by nitrogen fertilizer. Canadian Journal of Forest Research, 33:74-81. 